\title{
Combined traditional medicine and pharmacological antihypertensive drugs in a rural community of West Java, Indonesia
}

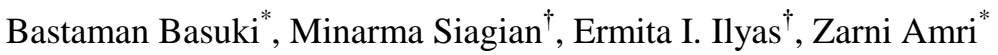

\begin{abstract}
Abstrak
Sebagian penderita tekanan darah tinggi di Indonesia menggunakan pengobatan tradisional di samping obat-obatan antihipertensif. Penelitian ini bertujuan untuk mengetahui hubungan antara beberapa pengobatan tradisonal seperti buah pace, belimbing, bawang putih, atau jamu, yang dipercaya dapat menurunkan tekanan darah pada hipertensi stage 1 dan 2. Data diperoleh dari hasil survai lapangan yang dilakukan oleh mahasiswa tingkat 2 Fakultas Kedokteran Universitas Indonesia tahun 2001, 2002, 2003 di Kabupaten Bogor, Jawa Barat. Subjek penelitian dipilih secara random dari klaster rukun tetangga. Wawancara dan pengukuran tekanan darah dilakukan di rumah subjek oleh mahasiswa yang terlatih di bawah pengawasan staf pengajar. Terdapat 496 subjek dengan hipertensi stage 1 dan 2 dan sebanyak 11,5\% menggunakan obat-obatan antihipertensi. Subjek hipertensi stage 2 yang minum obat antihipertensi 5,4 kali lipat jika dibandingkan dengan subjek hipertensi stage 1 (rasio odds suaian 5,44; 95\% interval kepercayaan = 2,64 - 11,27). Pengobatan tradisional yang dilakukan oleh subjek hipertensi terutama ketimun, belimbing, dan buah pace. Hal ini mungkin disebabkan kebiasaan yang kuat memakai obat tradisional dalam masyarakat, terbatasnya fasilitas kesehatan, dan harga obat antihipertensi yang mahal. Disimpulkan bahwa di daerah pedesaan, para penderita hipertensi melakukan pengobatan gabungan obat antihipertensi dengan obat-obat tradisional. (Med J Indones 2004; 13: 246-51)
\end{abstract}

\begin{abstract}
Some hypertensive subjects in Indonesia consume traditional herbal medicines in addition to the usual pharmacological drugs. This paper studied the relationship between several traditional herbal medicines, such as morinda, star fruit, garlic, or jamu, believed to control hypertension and the risk of current pharmacological antihypertensive drug users in subjects with stage 1 and 2 hypertension in a rural community West Java, Indonesia. The data were obtained from 3 field studies by the second year medical students of the Faculty of Medicine, University of Indonesia conducted in 2001, 2002, and 2003 in a subdistrict of the Bogor regency. The subjects were selected randomly from neighborhood clusters. Interviews and blood pressure measurements were conducted at the houses of the subjects by specially trained second year medical students supervised by faculty members. There were 496 subjects with stage 1 or 2 hypertension, with 11.5\% under current antihypertensive drugs. Compared with the hypertension stage 1 subjects, hypertension stage 2 subjects were 5.4 times more likely to be currently taking pharmacological antihypertensive medication (adjusted odds ratio = 5.44; $95 \%$ confidence interval $=2.64-11.27$ ). The combined of current antihypertensive medication with traditional medicines were cucumber which being the most dominant followed by star fruit and morinda. Reasons for this were probably the strong influence of culture, the limited medical facilities, and high cost of the antihypertensive drugs. It was concluded that in a rural Indonesia, it was common for hypertensive subjects to take pharmacological drugs as well as traditional medicine for antihypertensive therapy. (Med J Indones 2004; 13: 246-51)
\end{abstract}

Keywords : hypertension, pharmacological drugs, traditional medicine, Indonesia

Indonesia is in epidemiological transition with the double burden of communicable and non-communicable diseases. Among the non-communicable diseases currently on the rise is hypertension. ${ }^{1}$ In the previous

\footnotetext{
* Department of Community Medicine, Faculty of Medicine, University of Indonesia, Jakarta, Indonesia

${ }^{\dagger}$ Department of Physiology, Faculty of Medicine, University of Indonesia, Jakarta, Indonesia
}

reports, the prevalence of stage 1 and 2 hypertension was found to be quite high in a West Java rural community. However, only a small proportion of those with hypertension were currently on pharmacological antihypertensive treatment. ${ }^{2,3}$

In Indonesia, some hypertensive subjects consume traditional herbal medicines in addition to the usual pharmacological drugs. These traditional herbs, such as morinda, star fruit, garlic, and jamu, are believed to control hypertension. ${ }^{1,4,5}$ Jати is a traditional Indonesian 
medicine made from medicinal plants. The herbs or plants are grated, scraped, or crushed, then mixed together and boiled before taken as medicine. Although widely used throughout Indonesia, rural community-based hypertensive studies on combined treatment between traditional herbs or herbs and pharmacological drugs to control hypertension, is generally scarce in Indonesia.

This paper presents the relationship between several traditional food supplements or herbs and risk of current pharmacological antihypertensive drug users among hypertension stage 1 and 2 subjects in a rural community of West Java, Indonesia.

\section{METHODS}

This study used part of the data collected in three field studies by the second year medical students of the Faculty of Medicine, University of Indonesia, Jakarta. They were conducted mostly among the Sundanese ethnic group in a rural community of a sub district in the Bogor regency about $90 \mathrm{~km}$ south of Jakarta. Each survey was held for one day in July 2001, 2002, and 2003. Seven out of 18 different villages were randomly selected for each survey, then from each selected village 3 neighborhoods were chosen. The first available 25 adults, aged 18 years or more, were invited to participate.

Interviews and blood pressure measurements were conducted in the houses of the subjects by the 160 190 specially trained second year medical students under close supervision by faculty members of the Faculty of Medicine, University of Indonesia. Each faculty member supervised 4-5 medical students.

A special questionnaire form was used for the interview. The information collected was demographic characteristics such as gender, age, education, job, housing type, and daily working loads. Additional data about conditions and habits on drinking, meals, eating vegetables and fruits, smoking during the last six months were also asked. Furthermore, data on family history of illness such as hypertension, kidney diseases, diabetes mellitus, or thyroid diseases, use of pharmacological antihypertensive drugs, and use of traditional herbs (including vegetables and fruits believed to control hypertension) were collected.
Blood pressure was measured from 10:00 AM to 1:00 PM with mercury sphygmomanometers using the following techniques: ${ }^{1}$ the subject was seated in a chair with his/her back supported and his/her arms supported at heart level. Subjects were refrained from smoking and ingesting caffeine during the 30 minutes preceding measurement. Measurement began after at least 5 minutes of rest. Systolic blood pressures (SBP) and diastolic blood pressure (DBP) of both arms were recorded. The SBP was recorded at the first appearance of sound (phase 1), and the disappearance of sound (phase 5). The SBP and DBP were taken twice. If the SDP or DBP differed $5 \mathrm{~mm} \mathrm{Hg}$ or more on the two measurements, an additional measurement was done after about 5 minutes. The average of SBP and DBP taken were used to define the classification of the blood pressure.

Blood pressure was regarded normal or optimal when systolic blood pressure was less than $120 \mathrm{~mm} \mathrm{Hg}$ and diastolic blood pressure was less than $80 \mathrm{~mm} \mathrm{Hg}$. Prehypertension was diagnosed when SBP was 120-139 $\mathrm{mm} \mathrm{Hg}$ or DBP was $80-89 \mathrm{~mm} \mathrm{Hg}$. Stage 1 hypertension was diagnosed when SBP was 140-159 $\mathrm{mm} \mathrm{Hg}$, or DBP was $90-99 \mathrm{~mm} \mathrm{Hg}$, while stage 2 hypertension was diagnosed when SBP was more than $160 \mathrm{~mm} \mathrm{Hg}$ or DBP was $100 \mathrm{~mm} \mathrm{Hg}$ or more. ${ }^{6}$

The criteria for daily working loads were as follows: light daily working load if in general the tasks could be done in sitting or standing position, such as in clerks, household activities; moderate daily working load if the tasks resulted in an increase in breathing frequencies or sweating, such as in barbers; and heavy working load if the tasks needed muscular activity which will always result in an increase in both breathing frequencies and sweating, such as in blue color labor.

Only subjects having stage 1 and 2 hypertension (based on National Heart, Lung, and Blood Institute, USA $^{6}$ ) were analyzed. Subjects with normal blood pressure or pre-hypertension were excluded from this analysis. In addition, subjects who have had a history of pharmacological medication were also excluded.

Statistical analyses were done using STATA 6.0 software. ${ }^{7}$ Several risk factors were examined on the possibility of being potential confounders and/or effect modifiers. Unconditional logistic regression analysis $^{2}$ was used in order to determine the confounding effects and to determine the risk factors for hypertension. A risk factor was considered to be a potential confounder if in the univariate test it had a 
$P$-value $<0.25$ and would be considered as a candidate for the multivariate model along with all known risk factors for current pharmacological antihypertensive medication. ${ }^{8}$ Confounders were estimated by maximum likelihood. Ninety-five percent confidence intervals were based on the standard error of coefficient estimates. Odds ratios (OR) were estimated by maximum likelihood. ${ }^{9}$

Approval for this survey was granted by The Ethical Committee of the Department of Community Medicine, University of Indonesia, Jakarta.

\section{RESULTS}

A number of 1823 subjects participated in this study. From this number, 345 subjects with normal blood pressure, and 763 subjects with pre-hypertension were excluded. In addition, 219 subjects were also excluded for having a history of taking pharmacological antihypertensive drugs. There were 496 subjects left with either stage 1 or stage 2 hypertension for further analysis.

Table 1 showed that there were $11.5 \%$ (57/496) hypertensive subjects currently taking pharmacological antihypertensive drugs. Those who never had any antihypertensive drugs were similarly distributed with respect to gender and education in the 59 years or younger age group. However, there were more subjects who had never taken antihypertensive medication in the 60 years or more age group. Furthermore, it was noted that the prevalence of hypertensive subjects under current pharmacological antihypertensive drugs was low (11.5\%). However, the prevalence increased by age group, and reached highest prevalence in the 65 or more age group.

The subjects participating in 2002 and 2003 were less likely to be on antihypertensive drugs compared to those in 2001. There were also more married subjects who had never taken any antihypertensive drugs.

Table 2 showed that current smokers among hypertension stage 1 and 2 were $33.3 \%$ (160/496). Subjects currently on pharmacological antihypertensive medication were similarly distributed with respect to type of work (self-employed, employed, retired, or others, type of housing, family history of hypertension, and in the habit of eating garlic. In addition, there was no evidence of relationship between currently taking pharmacological antihypertensive medication to those in the habit of taking jamu once or twice a week or to those who had almost never take traditional herbs.
Table 1. Year of study and some demographic characteristics of subjects

\begin{tabular}{|c|c|c|c|c|}
\hline & \multicolumn{4}{|c|}{$\begin{array}{l}\text { Pharmacological } \\
\text { antihypertensive } \\
\text { medication }\end{array}$} \\
\hline & \multicolumn{2}{|c|}{$\begin{array}{c}\text { Never } \\
(\mathrm{N}=439\end{array}$} & \multicolumn{2}{|c|}{$\begin{array}{l}\text { Current } \\
(\mathrm{N}=57)\end{array}$} \\
\hline & $\mathrm{n}$ & $\%$ & $\mathrm{n}$ & $\%$ \\
\hline \multicolumn{5}{|l|}{ Gender } \\
\hline Male & 150 & 34.2 & 19 & 33.3 \\
\hline Female & 289 & 65.8 & 38 & 66.7 \\
\hline \multicolumn{5}{|l|}{ Marital status } \\
\hline Married & 361 & 82.2 & 38 & 66.7 \\
\hline Unmarried & 14 & 3.2 & 0 & 0 \\
\hline Divorced & 5 & 1.1 & 0 & 0 \\
\hline Widow & 51 & 11.6 & 17 & 29.8 \\
\hline Widower & 8 & 1.8 & 2 & 3.5 \\
\hline \multicolumn{5}{|l|}{ Age group (years) } \\
\hline $18-39$ & 131 & 29.8 & 5 & 8.8 \\
\hline $40-49$ & 89 & 20.3 & 6 & 10.5 \\
\hline $50-59$ & 99 & 22.6 & 7 & 12.3 \\
\hline $60-64$ & 41 & 9.3 & 12 & 21.1 \\
\hline $65-95$ & 79 & 18.0 & 27 & 47.4 \\
\hline \multicolumn{5}{|l|}{ Education } \\
\hline Illiterate or read only & 168 & 38.3 & 24 & 42.1 \\
\hline Primary school & 183 & 41.7 & 24 & 42.1 \\
\hline Junior or senior high school & 68 & 15.5 & 9 & 15.8 \\
\hline College or university & 8 & 1.8 & 0 & 0 \\
\hline Others & 12 & 2.7 & 0 & 0 \\
\hline \multicolumn{5}{|l|}{ Year of study } \\
\hline 2001 & 142 & 32.3 & 34 & 59.6 \\
\hline 2002 & 133 & 30.3 & 19 & 33.3 \\
\hline 2003 & 164 & 37.4 & 4 & 7.0 \\
\hline
\end{tabular}

When compared with housewives or those who were unemployed, the laborers were less likely to be on current pharmacological antihypertensive medication. Furthermore, those who almost never took jати had a moderate relationship $(\mathrm{p}=0.195)$ with currently taking pharmacological antihypertensive medication.

Table 3 showed that the hypertensive subjects combined their current pharmacological antihypertensive medication with traditional food supplements or herbs. The most dominant ones were cucumber, followed by star fruit and morinda. In the final model, taking star fruit and cucumber almost everyday were significantly related to currently taking pharmacological antihypertensive medication.

Compared with the hypertension stage 1 subjects, hypertension stage 2 subjects were 5.4 times more 
likely to be currently taking pharmacological antihypertensive medication. Furthermore, compared to those who almost never took morinda, the subjects who took morinda 1-2 times a week or almost everyday risked a two-fold increase to be currently on pharmacological antihypertensive medication.

Those taking star fruit everyday had almost a 4-fold relationship with currently taking pharmacological antihypertensive medication relative to those who almost never consumed star fruit as medication. In addition, compared to those who almost never took cucumber as medication, subjects taking cucumber 12 times a week had a moderately higher risk to be currently taking pharmacological antihypertensive medication, and for those who were taking cucumber almost everyday there was a five-fold greater risk to be on current pharmacological antihypertensive medication.

Table 2. Profession, housing type, family history on hypertension, and some habits of the subjects

\begin{tabular}{|c|c|c|c|c|}
\hline & \multicolumn{4}{|c|}{$\begin{array}{c}\text { Pharmacological } \\
\text { antihypertensive } \\
\text { medication }\end{array}$} \\
\hline & \multicolumn{2}{|c|}{$\begin{array}{c}\text { Never } \\
(\mathrm{N}=439)\end{array}$} & \multicolumn{2}{|c|}{$\begin{array}{l}\text { Current } \\
(\mathrm{N}=57)\end{array}$} \\
\hline & $\mathrm{n}$ & $\%$ & $\mathrm{n}$ & $\%$ \\
\hline \multicolumn{5}{|l|}{ Profession } \\
\hline None or housewife & 235 & 53.5 & 38 & 66.7 \\
\hline Laborer & 78 & 17.8 & 4 & 7.0 \\
\hline Self employed & 71 & 16.2 & 6 & 10.5 \\
\hline Employed & 20 & 4.6 & 1 & 1.8 \\
\hline Retired & 23 & 5.2 & 6 & 10.5 \\
\hline Others & 12 & 2.7 & 2 & 3.5 \\
\hline \multicolumn{5}{|l|}{ House type } \\
\hline Temporary & 11 & 2.5 & 2 & 3.5 \\
\hline Semi permanent & 67 & 15.3 & 9 & 15.8 \\
\hline Permanent & 361 & 82.2 & 46 & 80.7 \\
\hline \multicolumn{5}{|c|}{ Family history on hypertension } \\
\hline None & 289 & 65.8 & 34 & 59.6 \\
\hline Any & 118 & 26.9 & 17 & 29.8 \\
\hline Did not know & 32 & 7.3 & 6 & 10.5 \\
\hline \multicolumn{5}{|l|}{ Smoking habits } \\
\hline Never & 265 & 60.4 & 29 & 50.9 \\
\hline Ever & 33 & 7.5 & 9 & 15.8 \\
\hline Current & 141 & 12.1 & 19 & 33.3 \\
\hline \multicolumn{5}{|c|}{ Garlic (Allium sativum) } \\
\hline Almost never & 65 & 14.8 & 7 & 12.3 \\
\hline 1-2 times a week & 46 & 10.5 & 7 & 12.3 \\
\hline Almost everyday & 328 & 74.7 & 43 & 75.4 \\
\hline \multicolumn{5}{|l|}{ Jamu } \\
\hline Almost never & 125 & 28.5 & 16 & 28.1 \\
\hline 1-2 times a week & 227 & 51.7 & 22 & 39.4 \\
\hline Almost everyday & 87 & 19.8 & 18 & 31.5 \\
\hline
\end{tabular}

Table 3. Relationship between hypertension, traditional medication and risk of taking pharmacological antihypertensive medication

\begin{tabular}{|c|c|c|c|c|c|c|c|}
\hline & \multicolumn{4}{|c|}{$\begin{array}{c}\text { Pharmacological } \\
\text { antihypertensive } \\
\text { medication }\end{array}$} & \multirow{3}{*}{$\begin{array}{l}\text { Adjusted } \\
\text { odds } \\
\text { ratio* }\end{array}$} & \multirow{3}{*}{$\begin{array}{c}95 \% \\
\text { confidence } \\
\text { interval }\end{array}$} & \multirow{3}{*}{$\mathrm{p}$} \\
\hline & \multicolumn{2}{|c|}{$\begin{array}{c}\text { Never } \\
(\mathrm{N}=439)\end{array}$} & \multicolumn{2}{|c|}{$\begin{array}{l}\text { Current } \\
(\mathrm{N}=57)\end{array}$} & & & \\
\hline & $\mathrm{n}$ & $\%$ & $\mathrm{n}$ & $\%$ & & & \\
\hline \multicolumn{8}{|l|}{ Blood pressure } \\
\hline $\begin{array}{l}\text { Hypertension } \\
\text { stage } 1\end{array}$ & 283 & 64.5 & 15 & 26.3 & 1.00 & Reference & \\
\hline $\begin{array}{l}\text { Hypertension } \\
\text { stage } 2\end{array}$ & 156 & 35.5 & 42 & 73.7 & 5.44 & $2.64-11.27$ & 0.000 \\
\hline \multicolumn{8}{|l|}{ Morinda } \\
\hline Almost never & 373 & 85.0 & 39 & 68.4 & 1.00 & Reference & \\
\hline 1-2 times a week & 46 & 10.5 & 10 & 17.5 & 2.13 & $0.84-5.45$ & 0.113 \\
\hline Almost everyday & 20 & 4.6 & 8 & 14.1 & 2.37 & $0.75-7.45$ & 0.139 \\
\hline \multicolumn{8}{|l|}{ Star fruit } \\
\hline Almost never & 224 & 51.0 & 20 & 35.1 & 1.00 & Reference & \\
\hline 1-2 times a week & 173 & 39.5 & 21 & 36.8 & 1.41 & $0.66-3.04$ & 0.377 \\
\hline Almost everyday & 42 & 9.5 & 16 & 28.1 & 3.93 & $1.54-9.99$ & 0.004 \\
\hline \multicolumn{8}{|l|}{ Cucumber } \\
\hline Almost never & 63 & 14.4 & 3 & 5.3 & 1.00 & Reference & \\
\hline 1-2 times a week & 182 & 41.4 & 21 & 36.8 & 2.98 & $0.70-12.61$ & 0.139 \\
\hline Almost everyday & 194 & 44.2 & 33 & 57.9 & 4.96 & $1.21-20.33$ & 0.026 \\
\hline
\end{tabular}

\section{DISCUSSION}

Several limitations must be considered in the interpretation of the findings. Firstly, the analysis was limited to the relationship between current pharmacological antihypertensive therapy and traditional medication, particularly food supplements or herbs and јати. This relationship meant a risk marker between traditional medication and current pharmacological antihypertensive therapy, the attribute or exposure that is associated with an increase or decrease probability of current pharmacological antihypertensive therapy. It was not necessarily a causal factors. ${ }^{10}$ Secondly, there were no data on knowledge, attitude, or reasons for traditional and pharmacological antihypertensive medication. Thirdly, there were no data on the duration of the hypertension or the practice of traditional medication and pharmacological antihypertensive therapy.

Furthermore, the studies were conducted in a rural community with three hours for each session and involving 160-190 different medical students for each session. Although capable of taking blood pressure measurements, these second-year medical students did not have field experience.

These second-year medical students had passed physiology and were specially trained for this study, 
and they were supervised closely on-site by the faculty members during blood pressures measurements and interviews.

The data reveals that the prevalence of hypertension stage 1 and 2 subjects under current pharmacological antihypertensive drugs was low $(11.5 \%)$. This figure is less than in the other countries such as India. ${ }^{3}$ The prevalence of current pharmacological antihypertensive drug use increased among the elderly, and reached the highest among 65 or more age group. This finding is similar with a community-based study in India and Bangladesh that the elderly were found to be more on current antihypertensive medication. ${ }^{11}$

The data showed that current smokers among the hypertensives were high (33.3\%). This percentage is higher compared with the total studied subjects $(29.4 \%)$. The MONICA study in urban community in Jakarta (2000) revealed a lower prevalence of current smokers, i.e. $16.0 \%$ (personal communication). Since the prevalence of current smokers in this rural community was high, a special antismoking campaign should be intensively carried out.

The data showed that subjects with stage 2 hypertension were almost 3.5 times more likely on pharmacological antihypertensive therapy compared to those with stage 1 hypertension. Those with stage 2 hypertension were more likely to be aware of their condition or the effects of hypertension, such as headache or dizziness, stiffness in the neck, poor eyesight, tinnitus, insomnia, general weakness, etc. Moreover, they were more afraid of the effects of hypertension such as premature death or permanent disability. This finding was similar to a previous study. ${ }^{11}$

The final model showed that hypertensive subjects combined their current pharmacological antihypertensive medication with traditional food supplements or traditional medicine. The most dominant ones were cucumber, followed by star fruit and morinda. The use of traditional medicine in combination treatment with modern medicine have been reported in several countries. ${ }^{11-14}$

Morinda is believed to reduce hypertension, prevent inflammation, cure inflamed throats, hemorrhoids and allergies and reduce cholesterol, etc. ${ }^{4,5,12,14}$ Star fruit and cucumber are relatively easily available in a rural community and are good to eat. Morinda, on the other hand, was moderately associated to current pharmacological antihypertensive medication. The moderate association most likely due to the insufficient number of subjects needed to prove the significant association, or it could be that those taking morinda were the ones with severe hypertension.

There were several reasons for the high proportion of combined current pharmacological antihypertensive medication with traditional medicine. Firstly, the strong influence of culture for using traditional medicines in the Indonesian society, and the general trend in medication to go back to nature. ${ }^{4,5,14}$ Old stories on the healing properties of the medicinal plants have been transferred from generation to generation, and have been practiced for hundreds of years. Secondly, in rural areas the Community or Public Health Center, Hospital, or other modern medical facilities were generally limited and unevenly distributed. These modern medical facilities were far apart and therefore difficult to reach by the villagers. ${ }^{1}$ Thirdly, many people in rural areas cannot afford the relatively expensive synthetic drugs, especially during and after the economic crisis. ${ }^{1,4}$ Traditional medicine was apparently perceived as efficient, safe, cost effective, accessible and therefore more affordable, especially for the poor and for those living in remote areas. These villagers tend to depend more on traditional and herbal medicines than people living in urban areas. Furthermore, during the past decade, the use of traditional medicine has increased sharply, partly because formal health care became less accessible and less affordable due to the economic crisis in Indonesia. ${ }^{1}$

In spite of the wide use of traditional medicine, there has scarcely been any evidence-based medical proof in terms of efficacy and side effects. There have been no integration between modern health care systems and the traditional systems in Indonesia, they simply coexist, with the individual patients free to switch between the two or take both simultaneously. ${ }^{14}$

Herbal medicine is an increasingly common form of alternative therapy in the United States of America. It continues to have great appeal to patients and cannot be ignored. ${ }^{15}$ Furthermore, traditional in conjunction with pharmacological treatments hold great promise for a new paradigm for future collaboration. They have been some recent attempts to build a healthy collaboration creativity exhibited at the grass roots level in terms of traditional knowledge. ${ }^{16}$

In conclusion, combined pharmacological and traditional treatment, cucumber, star fruit, and morinda, 
for hypertension were more dominant among stage 2 hypertensive subjects. The background and reasons for this combined antihypertensive treatment need further studies.

\section{Acknowledgments}

The authors thank all subjects, the local leaders, and the second year medical students of the Faculty of Medicine, University of Indonesia, who cooperatively participated in this study. Special thanks to the faculty members who were in charge as on-site field supervisors for their high dedication.

\section{REFERENCES}

1. Ministry of Health of the Republic of Indonesia. Health profile on Indonesia 2000. Jakarta: The Ministry; 2001.

2. Basuki B, Setyanto B. Age, body posture, daily working loads, past anti hypertensive drugs and risk of hypertension: A rural Indonesian study. Med J Indones 2000;10:29-33.

3. Basuki B, Amri A, Soemarko DS, Ismail EI. Age, body posture, daily working load, past hypertensive drug and risk of hypertension: An Indonesia 2001 rural study. Med J Indones. 2001;11:224-9.

4. Unesco. Green Health: Indonesia jamu project. (Accessed May 1, 2003, at http://www.unesco.or.id/apgest/pdf/Indonesia/bp-gh-ri.pdf).

5. Suprijadi et al. Medicinal plants in Indonesia: The use and peculiar property [Indonesian]. Jakarta: Pustaka Populer; 2001.

6. National Heart, Lung, and Blood Institute (USA). The seventh report of the joint national committee on prevention, detection, evaluation, and treatment of high blood pressure. Bethesda. NIH Publication No. 03-5233; May 2003.

7. StataCorp. Stata statistical software: Release 6.0. Texas: College Station; 2000.

8. Hosmer DW, Lemeshow S. Applied logistic regression. $2^{\text {nd }}$ ed. New York: John Willey \& Sons; 2000.

9. Breslow NE, Day NE. Statistical methods in cancer research. Vol I. The analysis of case-control studies. IARC Sci Publ No.32. Lyon: International Agency for Research on Cancer; 1980.

10. Abramson JH. Making sense of data. 2nd ed. New York: Oxford; 1994.

11. Hypertension Study Group in India and Bangladesh. Prevalence, awareness, treatment and control of hypertension among the elderly in Bangladesh and India: a multicentre study. Bulletin of the World Health Organization. 2001:79;491-8.

12. Chaofan Z, Zhimin Y, Ruiquan L, Zhiming T. The principle and technique of using Chinese drugs in the treatment of hypertension. (Accessed May 2, 2003, at http://www.primeherbs.com/engstore/pdf/jtcm/cn21_1/07_11.pdf).

13. Akino TM, Nagki TI, Omatsu KK, Ano YK. Pharmacokinetic interactions between Japanese traditional medicine (Kampo) and modern medicine. (Accessed May 2, 2003, at http://denshi.pharm.or.jp/home/pubpharm/pubview.asp?p $=$ b040009).

14. Pramono E. The commercial use of traditional knowledge and medicinal plants in Indonesia. (Accessed May 10, 2004, at http://www.ictsd.org/dlogue/2002-0419/pramono.pdf).

15. De Smet PAGM. Herbal remedies. $N$ Engl J Med 2002;347:2046-56.

16. Balasubramanian AV. Traditional and modern sciences and technologies in India: trading new paradigms for old. (Accessed May 15, 2004, at http://www.millenniumassessment.org/ documents/bridging/papers/balasubramian.a.pdf). 